\title{
水平円管内を流動する極低温スラッシュ流体の流動・伝熱特性 に関する数值解析（SLUSH-3D）
}

\author{
大平 勝秀 ${ }^{* 1, \uparrow}$, 太田 敦人 ${ }^{* 2}$, 向井 康晃 ${ }^{* 3}$, 細野 玩已 ${ }^{* 1}$

\begin{abstract}
Numerical Study of Flow and Heat-transfer Characteristics of Cryogenic Slush Fluid in a Horizontal Circular Pipe (SLUSH-3D)
\end{abstract}

\author{
Katsuhide OHIRA $^{* 1, \uparrow}$, Atsuhito OTA ${ }^{* 2}$, Yasuaki MUKAI ${ }^{* 3}$ and Takumi HOSONO ${ }^{* 1}$
}

\begin{abstract}
Cryogenic slush fluids, such as slush hydrogen and slush nitrogen, are two-phase, single-component fluids containing solid particles in a liquid. Since their density and refrigerant capacity are greater than those of liquid-state fluids alone, there are high expectations for use of slush fluids as functional thermal fluids in various applications, such as fuels for spacecraft engines, clean energy fuels to improve the efficiency of transportation and storage, and as refrigerants for high-temperature superconducting equipment. In this research, a three-dimensional numerical simulation code (SLUSH-3D), including the gravity effect based on the thermal non-equilibrium, two-fluid model, was constructed to clarify the flow and heat-transfer characteristics of cryogenic slush fluids in a horizontal circular pipe. The calculated results of slush nitrogen flow performed using the numerical code were compared with the authors' experimental results obtained using the PIV method. As a result of these comparisons, the numerical code was verified, making it possible to analyze the flow and heat-transfer characteristics of slush nitrogen with sufficient accuracy. The numerical results obtained for the flow and heat-transfer characteristics of slush nitrogen and slush hydrogen clarified the effects of the pipe inlet velocity, solid fraction, solid particle size, and heat flux on the flow pattern, solidfraction distribution, turbulence energy, pressure drop, and heat-transfer coefficient. Furthermore, it became clear that the difference of the flow and heat-transfer characteristics between slush nitrogen and slush hydrogen were caused to a large extent by their thermo-physical properties, such as the solid-liquid density ratio, liquid viscosity, and latent heat of fusion.
\end{abstract}

Keywords: slush nitrogen, slush hydrogen, solid-liquid two-phase flow, turbulent pipe flow, hydrogen energy

\section{1. はじめに}

極低温固液二相スラッシュ流体は、高密度流体、冷媒と して優れた特性を持っている。スラッシュ流体の実用上代 表的なものとして、温度 $14 \mathrm{~K}$ のスラッシュ水素と温度 63 K のスラッシュ窒素がある。重量固相率 50 wt.\%（体積固

Received June 20, 2011

${ }^{* 1}$ 東北大学 流体科学研究所 極低温流研究分野

干980-8577 宮城県仙台市青葉区片平 2-1-1

Institute of Fluid Science, Tohoku University,

2-1-1 Katahira, Aoba-ku, Sendai, Miyagi 980-8577, Japan

*2 三菱商事(株)

干100-8086 東京都千代田区丸の内 2-6-1

Mitsubishi Corporation

2-6-1 Marunouchi, Chiyoda-ku, Tokyo 100-8086, Japan

*3 AGC 旭硝子(株)

干230-0045 神奈川県横浜市鶴見区未広町 1-1

Asahi Glass Co., Ltd.

1-1 Suehiro-cho, Tsurumi-ku, Yokohama, Kanagawa 230-0045,

Japan

† E-mail: ohira@luna.ifs.tohoku.ac.jp
相率 $47 \mathrm{vol} \%$ \% ) のラッシュ水素の場合、温度 $20 \mathrm{~K}$ の液 体水素と比較して密度が $16 \%$ 、寒冷保有量（エンタル ピ）が 18\%増加する。重量固相率 50 wt.\% (46 vol.\%) の スラッシュ窒素もスラッシュ水素と同様、密度が $16 \%$ 、 寒冷保有量が $22 \%$ 増加する。スラッシュ水素を利用する と、水素の効率的な輸送、貯蔵が可能になると共に、機器 の高性能化、小型・軽量化が期待できる。

燃料電池の飛躍的な普及、情報技術による電力需要増加 に鑑み、著者は Fig. 1 に示す水素エネルギーシステムを提 案して ${ }^{1)}$ 、図中の左上に示す研究・開発を実施してきた。 水素をスラッシュ水素の形態で長距離（パイプライン）輸 送する際、 $\mathrm{MgB}_{2}$ を利用した超伝導送電および超伝導電力 貯蔵と組み合わせると、然料と電力の輸送および貯蔵が同 時に可能となる。即ち、シナジ一効果が期待できる。また、 極低温スラッシュ流体が配管中を流動する際、侵入熱や超 伝導線のクエンチによる発熱がある場合、熱の一部は固体 の融解熱で吸収され、固相率は低下するが、液体の温度上 
昇は低減される。冷媒およびエネルギー輸送媒体の働きを する機能性熱流体として優れた特性を保有している。

これまでに報告されたスラッシュ流体の主な実験的研究 として、水平管内を流動するスラッシュ水素の圧力損失特 性 ${ }^{2)}$ 、低流速で水平管内を流動するスラッシュ窒素の圧力 損失および熱伝達特性 ${ }^{3)}$ 、高流速で水平管内を流動するス ラッシュ窒素の圧力損失低減および熱伝達劣化特性 ${ }^{4 \sim 7) 、}$ オーガ法およびフリーズ・ソー法によるスラッシュ水素製 造法 ${ }^{8,9)}$ 、スラッシュ水素用密度計および流量計の開発 10 13) などが挙げられる。一方、スラッシュ流体の流動特性を解 明するための数值解析研究は少なく、主なものとして、三 次元水平管内およびベンチュリ管内の流動解析 14, 15)、二 次元水平管内および収縮・拡大管内の流動解析 ${ }^{16)}$ が報告 されている。しかしながら、これらの研究ではスラッシュ 流体の実験データが少ないことから、解析モデルと手法の 検証に不十分な点が見受けられ、流速や固相率の変化、固 体粒子径の違い、管外部からの伝熱がスラッシュ流体の流 動に及ぼす影響について十分に解析がなされていない。

スラッシュ流体が水平円管内を流動する際の流動・伝熱 特性を解明するため、著者はこれまでスラッシュ窒素を用 いて実験研究を行ってきた。スラッシュ窒素が管内を流動 する際の圧力損失特性に関し、実用上重要となる管内流速 が大きい場合、スラッシュ窒素の圧力損失が液体窒素より 減少する、もしくは液体窒素の圧力損失に近づくという非 ニュートン流体的な挙動である圧力損失低減を報告してい る 4 7)。また、水平伝熱管内を流動するスラッシュ窒素の 強制対流熱伝達特性に関しても、圧力損失低減に起因する 熱伝達劣化について著者は初めて報告している ${ }^{5,7)}$ 。高速 度ビデオカメラおよび粒子画像流速測定法（PIV：Particle Image Velocimetry) による可視化観察結果から、内径 15 $\mathrm{mm} 、 10 \mathrm{~mm}$ 管の場合、流速が各々 3.6、2.0 m/s 付近で非 均質流から擬均質流へ固体粒子の流動パターンが変化して おり、圧力損失低減効果が擬均質流において認められ

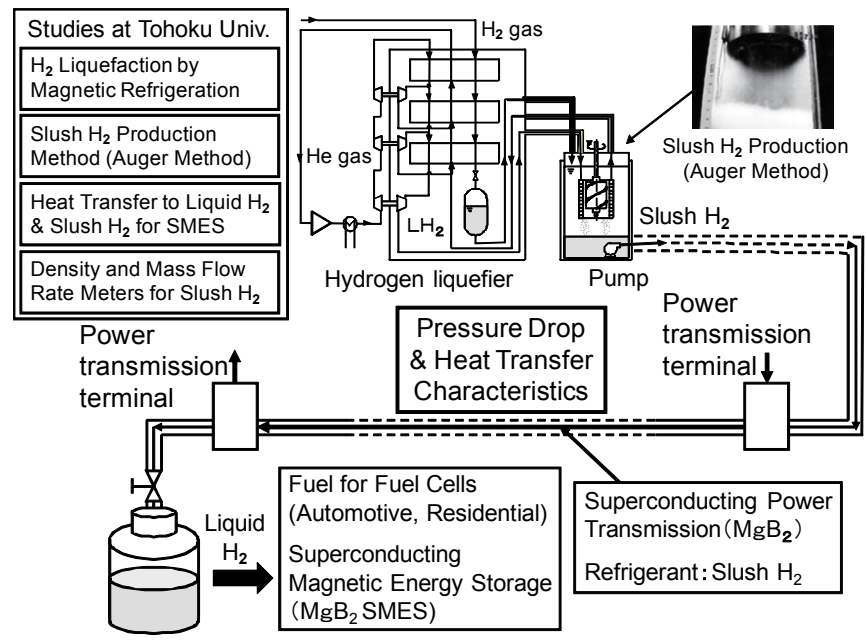

Fig. 1 Synergetic effect of the combination of slush hydrogen and high-temperature superconducting equipment.
た ${ }^{4 \sim 7)}$ 。擬均質流において管中心部へ移動した固体粒子群 が、管壁での乱流発達と管中心部への乱流拡散および熱拡 散を抑制していることが圧力損失低減および伝熱劣化の原 因と考えられる。以上のように、スラッシュ流体をパイプ ライン輸送の媒体や超伝導送電の冷媒として利用する際、 必要とされるスラッシュ流体の管内流動・伝熱特性は未だ 充分に解明されていない。

本研究では、スラッシュ流体の水平管内流動・伝熱特性 を解明するため、重力の影響を含む三次元二流体モデルに 基づく基礎方程式を構築し、スラッシュ窒素、スラッシュ 水素の流動・伝熱特性について解析を行った。開発した解 析コード（SLUSH-3D）では、非ニュートン流体的挙動で ある圧力損失低減および熱伝達劣化現象が、現状十分に解 明されていないため考慮していない。従って、スラッシュ 流体をニュートン流体と仮定している。数值解析結果を PIV 法および伝熱試験から得られたスラッシュ窒素実験結 果 ${ }^{6,7)}$ と比較した結果、解析手法および解析結果の妥当性 が確認されたので、本解析コードを使用して、スラッシュ 流体の水平円管内流動・伝熱特性について解明を行った。

\section{2. 数值解析手法}

本研究では、水平円管内を流れるスラッシュ流体の三次 元流動・伝熱を解析対象とし、固相の融解に基づく固相と 液相間の質量、運動量およびエネルギー交換を考慮した熱 非平衡二流体モデルを用いて三次元流動・伝熱解析を実施 する。本数值解析では、粒子分散系である固相を連続相と して扱う Euler-Euler カップリング法に基づく、計算負荷 の小さい二流体モデルを採用している。また、固相および 液相は圧力による密度変化が小さいので、計算負荷を低減 するため非圧縮性流体を仮定する。PISO (Pressure Implicit with Splitting of Operator) 法 ${ }^{17)}$ を流体の圧力を計算する方 法として使用した。さらに、固相と液相のカップリングを 考える場合、液相流れ場は固体粒子径の影響を受け、固相 流れ場も粒子径に応じて液相流れ場から影響を受けると考 え、固相は流体で連続相でありながら分散相として扱える よう直径 $d_{s}$ の球形の擬固体と仮定する。固体粒子同士の 衝突、固体粒子と壁面の衝突は考慮していない。論文の最 後に記号表を示す。

\section{1 支配方程式}

熱非平衡流体モデルに基づく平均化操作を施した支配方 程式を以下に示す。相変化を考慮した連続の式を式(1)に 示す。添字 $\varphi=s$ は固相、 $\varphi=l$ は液相、 $\alpha_{s}$ は体積固相率 を表し、 $\alpha_{s}+\alpha_{l}=1$ である。

$$
\frac{\partial\left(\alpha_{\varphi} \rho_{\varphi}\right)}{\partial t}+\nabla \cdot\left(\alpha_{\varphi} \rho_{\varphi} \boldsymbol{U}_{\varphi}\right)=\dot{m}_{\varphi}
$$

ここで、右辺は固相の融解による相間質量交換項である。

次に、相変化を考慮した運動量保存式を式(2)に示す。 圧力 $P$ は固液二相の平均圧力に等しいと仮定し、 $P=\alpha_{s} P_{s}$ 
$+\alpha_{l} P_{l}$ とする。

$$
\begin{aligned}
& \frac{\partial\left(\alpha_{\varphi} \rho_{\varphi} \boldsymbol{U}_{\varphi}\right)}{\partial t}+\nabla \cdot\left(\alpha_{\varphi} \rho_{\varphi} \boldsymbol{U}_{\varphi} \boldsymbol{U}_{\varphi}\right)+\nabla \cdot\left(\alpha_{\varphi} \rho_{\varphi} \boldsymbol{R}_{\varphi}^{e f f}\right) \\
& =-\alpha_{\varphi} \nabla P+\alpha_{\varphi} \rho_{\varphi} \mathbf{g}+\boldsymbol{M}_{T \varphi}+\boldsymbol{M}_{\varphi}
\end{aligned}
$$

ここで、実効レイノルズ応力 $\boldsymbol{R}_{\varphi}^{e f f}$ は式(3)に示すレイノル ズ応力 $\boldsymbol{R}_{\varphi}$ と粘性応力テンソル $\tau_{\varphi}$ を含む $\tau_{\varphi} / \rho_{\varphi}$ の和である。

$$
\boldsymbol{R}_{\varphi}^{e f f}=\boldsymbol{R}_{\varphi}+\frac{\boldsymbol{\tau}_{\varphi}}{\rho_{\varphi}}=-v_{\varphi}^{e f f}\left(\nabla U_{\varphi}+\nabla U_{\varphi}{ }^{T}-\frac{2}{3} \mathbf{I} \nabla \cdot U_{\varphi}\right)+\frac{2}{3} \mathbf{I} \cdot k
$$

実効動粘性係数 $v_{\varphi}^{e f f}$ は乱流の影響を考慮した渦動粘性係数 $v_{l}^{t}$ を用いて式(4)、(5)で与える。

$$
\begin{aligned}
& v_{l}^{\text {eff }}=v_{l}+v_{l}^{t}=v_{l}+C_{\mu} \frac{k^{2}}{\varepsilon} \\
& v_{s}^{\text {eff }}=v_{s}+C_{t}^{2} v_{l}^{t}
\end{aligned}
$$

ここで、 $C_{\mu}=0.09 、 C_{t}=1.0 、 v_{s}=10 v_{l}$ である ${ }^{18)}$ 。式(2)の 相変化による界面運動量輸送項 $\boldsymbol{M}_{T \varphi}$ は式(6)で与える。

$$
\boldsymbol{M}_{T s}=-\boldsymbol{M}_{T l}=-\boldsymbol{U}_{s} \max \left(-\dot{m}_{s}, 0\right)+\boldsymbol{U}_{l} \max \left(-\dot{m}_{l}, 0\right) \text { (6) }
$$

界面運動量輸送項 $\boldsymbol{M}_{\varphi}$ には、固相と液相間に働く抗力、固 相と液相間の相対速度 $\boldsymbol{U}_{r}=\boldsymbol{U}_{s}-\boldsymbol{U}_{l}$ による運動量変化が引 き起こす仮想質量力のみを本解析では考慮しており ${ }^{19)}$ 、 それぞれ式(7)、(8)、(9)で与える。

$$
\begin{aligned}
& \boldsymbol{M}_{s}=-\boldsymbol{M}_{l}=\boldsymbol{M}_{s}^{\text {drag }}+\boldsymbol{M}_{s}^{\text {virtual mass }} \\
& \boldsymbol{M}_{s}^{\text {drag }}=\frac{\mathrm{A}_{2}}{2 \mathrm{~A}_{3}} \alpha_{s} \alpha_{l}\left(\frac{\alpha_{l} \rho_{l} C_{d}}{d_{s}}\right) \boldsymbol{U}_{r} \mid \boldsymbol{U}_{r} \\
& \boldsymbol{M}_{s}^{\text {virtual mass }}=\alpha_{s} \alpha_{l}^{2} \rho_{l} C_{v m}\left(\frac{\mathrm{D} \boldsymbol{U}_{l}}{\mathrm{D} t}-\frac{\mathrm{D} \boldsymbol{U}_{s}}{\mathrm{D} t}\right)
\end{aligned}
$$

ここで、 $A_{2}=\pi / 4 、 A_{3}=\pi / 6$ はそれぞれ固体粒子の 2 次元形 状係数、3 次元形状係数、仮想質量力係数 $C_{v m}=0.5$ であ る。式(8)の抗力係数 $C_{d}$ には固相と液相の相対レイノルズ 数 $R e_{r}$ により評価する Schiller-Naumann の抗力モデル ${ }^{20) を ~}$ 使用した。

次に、エネルギー保存式を式(10)に示す。

$$
C_{p, \varphi} \rho_{\varphi}\left(\frac{\partial\left(\alpha_{\varphi} T_{\varphi}\right)}{\partial t}+\nabla \cdot\left(\alpha_{\varphi} U_{\varphi} T_{\varphi}\right)\right)=\nabla \cdot\left(\alpha_{\varphi} \kappa_{\varphi}^{\text {eff }} \nabla T_{\varphi}\right)+Q_{L, \varphi}+Q_{\varphi}
$$

$\kappa_{\varphi}{ }^{e f f}$ は実効熱伝導係数であり、固相の場合、 $\kappa_{s}^{e f f}=\kappa_{s}$ 、液 相の場合、液相の熱伝導係数と乱流による熱拡散効果を考 慮して式(11)で表される。

$$
\kappa_{l}^{e f f}=\kappa_{l}+C_{p, l} \rho_{l} v_{l}^{t}
$$

固相の融解による相変化を考慮した界面熱輸送項 $Q_{L, \varphi}$ は、式(12)で表される。

$$
Q_{L, s}=-Q_{L, l}=\dot{m}_{s} h_{L}
$$

粒子と液相間の強制対流による熱伝達量 $Q_{\varphi}$ は式(13)で表 される。ヌッセルト数 $N u$ として、Ranz-Marshall の熱拡散 モデル ${ }^{21)}$ を使用した。ここで、 $n$ は粒子数密度である。

$$
Q_{s}=-Q_{l}=n N u \pi d_{s} \kappa_{l}\left(T_{l}-T_{s}\right)
$$

伝熱時は、最初にエネルギー保存式(10)を管内壁からの伝 熱のみを考慮して計算する。即ち、式(10)の液相の右辺は $Q_{L, l}=0$ とし、固相の右辺は $Q_{s}$ のみを考慮する。次に、固
相の融解による固相と液相の密度変化を式(14)の温度回復 法により計算し、密度変化後の温度分布、界面熱輸送量の 修正を行っている。

$$
\begin{array}{lr}
\dot{m}_{s}=0 & \text { for } T_{s} \leq T_{t r} \text { and } T_{l} \geq T_{t r} \\
\dot{m}_{s}=-n N u \pi d_{s} \kappa_{l}\left(T_{s}-T_{t r}\right) / h_{L} & \text { and } T_{s}=T_{t r} \\
& \text { for } T_{s}>T_{t r} \text { and } T_{l} \geq T_{t r}
\end{array}
$$

管壁温度 $T_{\text {wall }}$ は、管内壁に接するセルの中心温度 $T_{\text {cell }}$ 、熱 流束 $q$ 、管壁とセル中心の距離 $d_{\text {cell }}$ から式(15)で計算す る。

$$
T_{\text {wall }}=T_{\text {cell }}+\frac{q}{\kappa_{l}^{e f f}} d_{\text {cell }}
$$

また、粒子は流動場において流体力や液相との干渉によ り拡散するため、粒子の拡散に関する保存式が必要とな る。本解析では、粒子の拡散を粒子数密度の分布によりモ デル化する。粒子数密度保存の式は、粒子の拡散が等方的 であると仮定して式(16)で与える。

$$
\frac{\partial n}{\partial t}+\nabla \cdot\left(U_{s} n-\frac{v_{l}^{t}}{S c^{t}} \nabla n\right)=0
$$

$n$ は粒子数密度であり、Sc $c^{t}$ は乱流シュミット数 $\left(S c^{t}=\right.$ 0.77）である。体積固相率、粒子数密度、粒子径には式 (17)の関係が成立する。

$$
\alpha_{s}=n \frac{1}{6} \pi d_{s}^{3}
$$

\section{2 乱流モデル}

本数值解析では、乱流モデルとして壁関数を用いた標準 $k-\varepsilon$ モデルを採用し、乱流モデルは液相にのみ適用する。 $k$ 方程式および $\varepsilon$ 方程式は固相率の影響を受けるとして、そ れぞれ式(18)、(19)で与える。

$$
\begin{aligned}
& \frac{\partial\left(\alpha_{l} k\right)}{\partial t}+\nabla \cdot\left(U_{l} k\right)-\nabla \cdot\left(\sigma_{k} v_{l}^{e f f} \nabla k\right)=\alpha_{l} G-\alpha_{l} \varepsilon \\
& \frac{\partial\left(\alpha_{l} \varepsilon\right)}{\partial t}+\nabla \cdot\left(U_{l} \varepsilon\right)-\nabla \cdot\left(\sigma_{\varepsilon} v_{l}^{e f f} \nabla \varepsilon\right)=\left(C_{1} \alpha_{l} G-C_{2} \alpha_{l} \varepsilon\right) \frac{\varepsilon}{k}
\end{aligned}
$$

$G$ は乱れエネルギー生成項であり、内積で表される式(20) である。

$$
G=v_{l}^{t}\left(\left(\nabla \boldsymbol{U}_{l}\right):\left(\left(\nabla \boldsymbol{U}_{l}+\left(\nabla \boldsymbol{U}_{l}\right)^{T}\right)-\frac{2}{3} \mathrm{I} \nabla \cdot \boldsymbol{U}_{l}\right)\right)
$$

ここで、 $\sigma_{k}=1.0 、 \sigma_{\varepsilon}=1.3 、 C_{1}=1.44 、 C_{2}=1.92$ である ${ }^{18)}$ 本解析で採用している乱流モデルでは、乱れエネルギー $k$ とエネルギー散逸率 $\varepsilon$ が独立変数となっているが、この 前提が成立するのは高 $R e$ 数領域である。したがって、Re 数が小さい壁面近傍では、壁関数を用いて計算領域外縁で の乱れエネルギー $k$ とエネルギー散逸率 $\varepsilon$ を算出した。

\section{3 数值解析条件}

本解析では、変数の離散化に有限体積法を用いた。二流 体モデルを採用しているため、固相率変化等により、変数 や物性值の不連続性が発生することが予想され、対流項の 離散化にあたっては単調性を維持できる必要性がある。そ こで、対流項の離散化にあたっては、単調性が維持でき、 


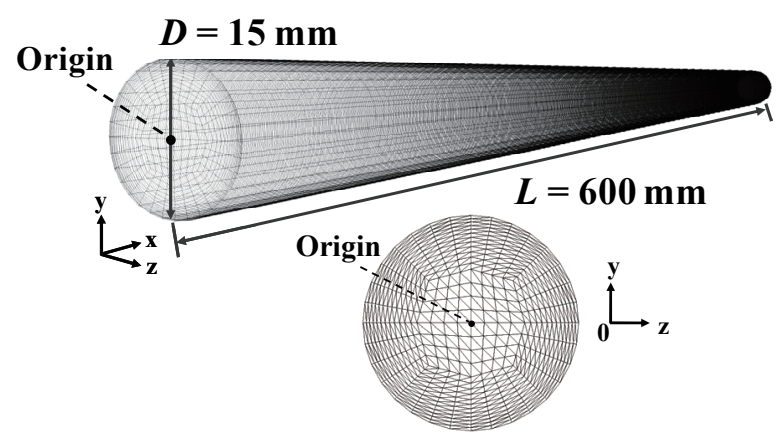

Fig. 2 Schematic of the grid system used for the numerical analysis.

流れのスムーズなところでは高次精度を維持し、不連続な 部分では数值振動を抑制する二次精度 TVD スキームを採 用した。また、基幹 CFD ソルバーのコーデイングには OpenFOAM ${ }^{22)}$ を用いた。さらに、拡散項の離散化にあ たっては数值安定性の高い二次精度中心差分を用い、時間 積分にあたっては安定性の良いEuler 陰解法を用いた。

解析に用いた水平円管は、管内径 $D=15 \mathrm{~mm}$ 、管路長 $L$ = $600 \mathrm{~mm}$ であり、流路モデルを Fig. 2 に示す。解析に使 用した計算格子は構造格子であり、流路方向の格子幅は $1.5 \mathrm{~mm}$ 、断面における最大格子幅は $0.875 \mathrm{~mm}$ 、壁面近傍 での最小格子幅は $0.19 \mathrm{~mm}$ である。また、セル数は 448 (円形断面） $\times 400$ （流路方向）=179200 である。計算值 が定常となる流路入口から $L=400 \mathrm{~mm}$ における計算值を 結果として用いた。

各変数の入口条件は一定值で与える。壁面における境界 条件は、流速についてはノンスリップ条件で与えるが、そ の他の変数についてはノイマン条件で与える。出口条件に ついては、全ての変数についてノイマン条件で与える。た だし、圧力 $P$ は出口で大気圧 $(0.1 \mathrm{MPa})$ とする。計算に 用いたスラッシュ窒素、スラッシュ水素の三重点物性值を

Table 1 に示寸 ${ }^{23,24)}$ 。入口流速を $U_{i n}=1.5 、 2.0 、 3.0 、 4.0$ 、 $5.0 \mathrm{~m} / \mathrm{s}$ 、初期体積固相率を $\alpha_{\mathrm{s}}=0.05 、 0.13 、 0.20 、 0.25$ と

Table 1 Thermo-physical properties of nitrogen and hydrogen.

\begin{tabular}{|l|l|r|r|}
\hline \multicolumn{1}{|c|}{ Thermophysical property } & \multicolumn{1}{|c|}{ Symbol } & \multicolumn{2}{c|}{ Nitrogen Hydrogen } \\
\hline Solid density & $\rho_{s}\left[\mathrm{~kg} / \mathrm{m}^{3}\right]$ & 1026.5 & 86.59 \\
\hline Liquid density & $\rho_{l}\left[\mathrm{~kg} / \mathrm{m}^{3}\right]$ & 867.86 & 77.01 \\
\hline Liquid viscosity & $\mu^{l}\left[10^{-3} \mathrm{~Pa}-\mathrm{s}\right]$ & 0.292 & 0.0258 \\
\hline Kinematic viscosity of liquid & $v_{l}\left[\mu \mathrm{m}^{2} / \mathrm{s}\right]$ & 0.336 & 0.335 \\
\hline Specific heat of solid & $C_{p, s}[\mathrm{~J} /(\mathrm{kg}-\mathrm{K})]$ & 1.66 & 2.6 \\
\hline Specific heat of liquid & $C_{p, l}[\mathrm{~J} /(\mathrm{kg}-\mathrm{K})]$ & 2 & 6.53 \\
\hline Thermal conductivity of solid & $\kappa_{s}[\mathrm{~W} /(\mathrm{m}-\mathrm{K})]$ & 0.2 & 0.129 \\
\hline Thermal conductivity of liquid & $\kappa_{l}[\mathrm{~W} /(\mathrm{m}-\mathrm{K})]$ & 0.162 & 0.103 \\
\hline Latent heat of fusion & $h_{L}[\mathrm{~kJ} / \mathrm{kg}]$ & 25.56 & 62.8 \\
\hline Triple point temperature & $T_{t r}[\mathrm{~K}]$ & 63.15 & 13.81 \\
\hline Initial temperature of solid & $T_{s}[\mathrm{~K}]$ & 63.1 & 13.8 \\
\hline Initial temperature of liquid & $T_{l}[\mathrm{~K}]$ & 63.2 & 13.9 \\
\hline
\end{tabular}

して、流速、固相率が変化する場合の流動・伝熱構造を解 析した。著者がフリーズ・ソー法にて製造したスラッシュ 窒素の固体粒子径（絶対最大值）の平均值は $1.36 \mathrm{~mm}^{4,6)}$ であるが、オーガ法では粒子径を小さくできるため ${ }^{8,9) 、}$ 粒子径 $d_{s}=0.5 、 1.3 \mathrm{~mm}$ の二種類について計算を行った。 以下、特に記述がなければ、 $U_{i n}=2.0 、 5.0 \mathrm{~m} / \mathrm{s} 、 \alpha_{s}=0.13$ 、 $d_{s}=1.3 \mathrm{~mm}$ の解析結果を図に示す。また、加熱時の熱流 束は実験と同じ $q=10 、 30 \mathrm{~kW} / \mathrm{m}^{2}$ とした。固相と液相間 の初期温度差を Table 1 に示すように $0.1 \mathrm{~K}$ と設定し、伝 熱時の温度変化による固相と液相の物性值変化は考慮せず、 三重点での物性值を用いた。

\section{3. 数值解析結果および考察}

\section{1 解析プログラムの妥当性評価}

Fig. 3 にスラッシュ窒素の低流速、高流速時における固 相の $x$ 方向流速分布の解析結果を示寸。また、固体窒素粒 子を直接トレーサとする PIV 実験で得られた固体窒素粒 子の $x$ 方向流速分布を示す。スラッシュ窒素の実験に用い た水平円管は内径 $15 \mathrm{~mm}$ 、圧力損失測定長さ $400 \mathrm{~mm}$ であ り、可視化管の内径も $15 \mathrm{~mm}$ である ${ }^{6)}$ 。横軸は固相流速

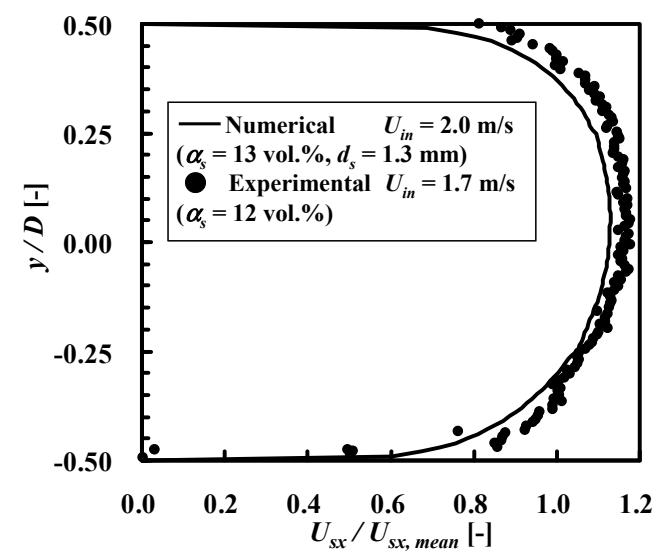

(a) Low inlet velocity.

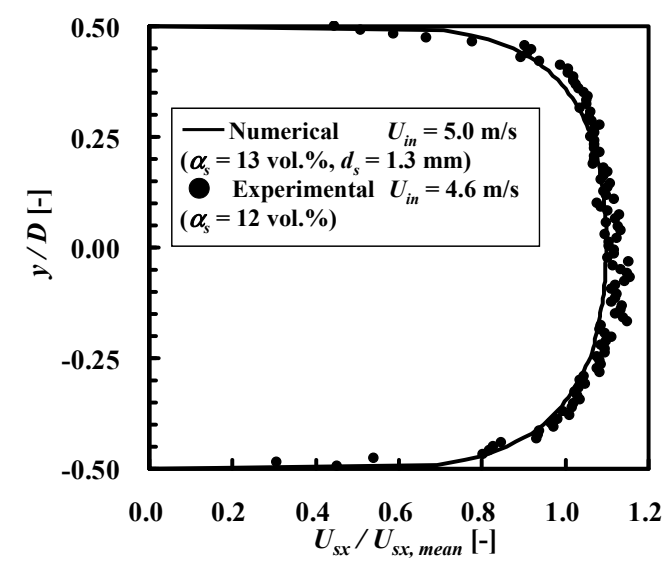

(b) High inlet velocity.

Fig. 3 Solid-phase velocity profiles of the numerical and experimental results for the slush nitrogen $\left(d_{s}=1.3 \mathrm{~mm}\right)$. 


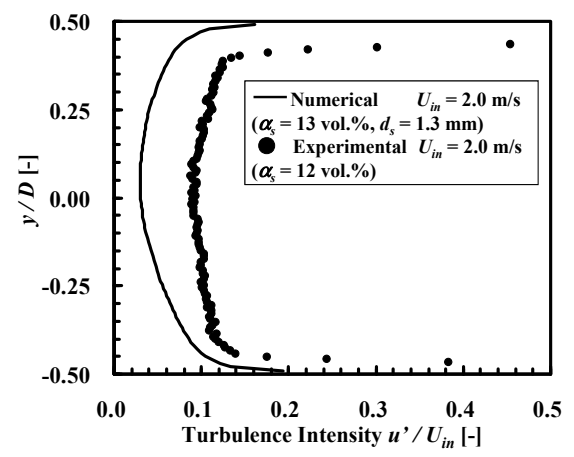

(a) Low inlet velocity.

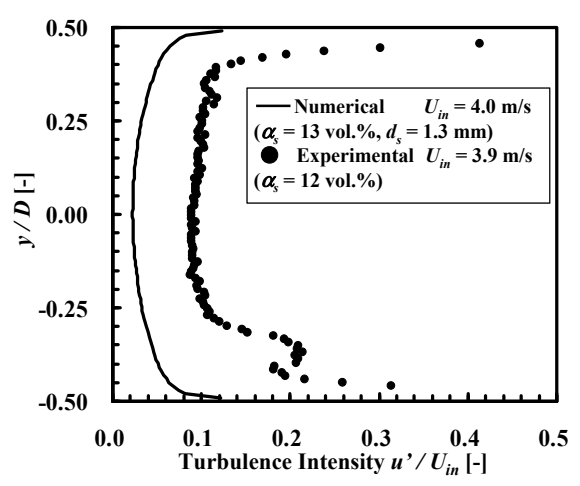

(b) High inlet velocity.

Fig. 4 Comparisons of the relative turbulence intensity between the numerical (liquid-phase) and experimental (solidphase) results for the slush nitrogen $\left(d_{s}=1.3 \mathrm{~mm}\right)$.

を固相の平均流速で規格化した值であり、縦軸は管中心軸 を通る鉛直面上の位置を示している。 $y / D=-0.5$ は流路底 部壁面、 $y / D=0.0$ は流路中心、 $y / D=0.5$ は流路上部壁面 を示している。低流速、高流速のいずれの場合も、数值解 析結果と PIV 実験結果は良い一致を示している。また、 3.3 で述べるサブクール液体窒素の圧力損失解析結果が Prandtl-Karman 式を用いて計算した平滑円管の圧力損失と 良く一致している（Fig. 8(a)参照）。次に、低流速および 高流速時の液相の $x$ 方向相対乱流強度 $u^{\prime} / U_{i n}$ の数值解析結 果と PIV 実験結果を Fig. 4 に示す。横軸は乱流強度を入 口流速で規格化した值である ${ }^{25)}$ 。高流速時の $y / D=-0.3 \sim$ -0.4での実験值はレーザ光のハレーションにより実際の值 とは異なる。両者の乱流強度は数值解析結果の方が実験結 果よりも小さい值となっているが、定性的には一致してい る。2.2 で述べたように、乱流モデルは液相にのみ適用し ているため、解析結果は液相の乱流強度であり、実験結果 は固体粒子（固相）の乱流強度である。また、数值解析結 果は理想的な平滑円管の乱流場であるため、実際の流動と 比較して乱流強度の值が小さくなっていると考えられる。 以上のことから、開発した数值解析コード（SLUSH-3D） はスラッシュ流体の流動を十分な精度で解析できると考え る。

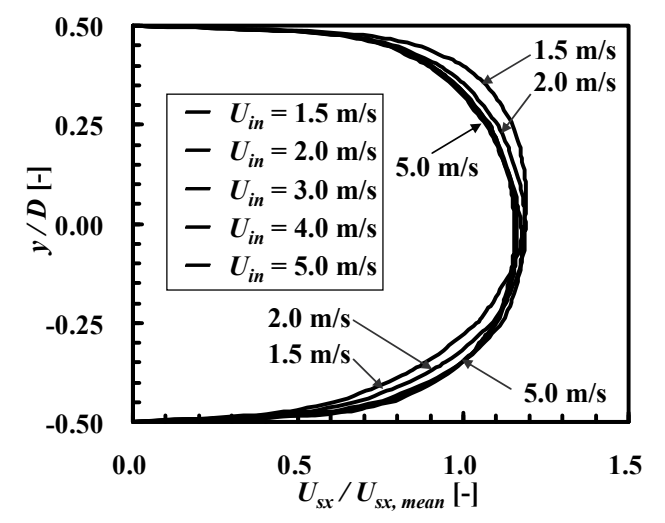

(a) Slush nitrogen.

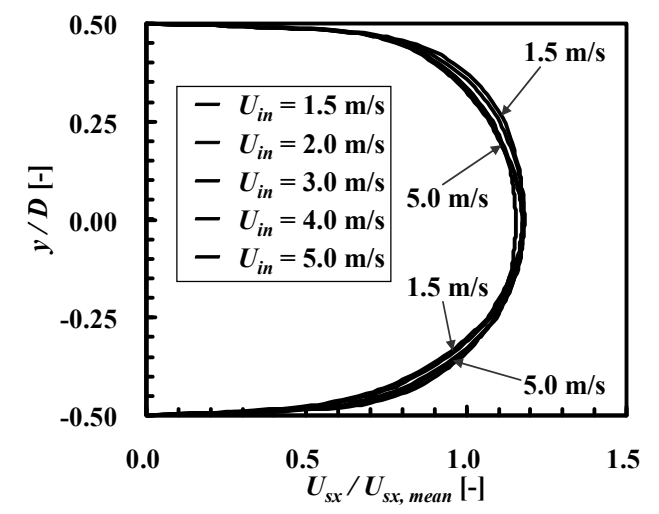

(b) Slush hydrogen.

Fig. 5 Solid-phase velocity profiles according to changes in the inlet velocity $\left(d_{s}=1.3 \mathrm{~mm}, a_{s}=13\right.$ vol. $\left.\%\right)$.

\section{2 円管内流動特性}

スラッシュ窒素、スラッシュ水素の入口流速 $U_{i n}=$ 1.5 5.0 m/s での固相の $x$ 方向流速分布を Fig. 5 に示す。横 軸は $x$ 方向流速を $x$ 方向平均流速で規格化した值である。

Fig. 6 に同じ入口流速範囲での管内局所固相率を示す。ま た、Fig. 7 に固体粒子径 $d_{s}=0.5 、 1.3 \mathrm{~mm}$ での管断面にお ける固相率分布を示す。Fig. 5 (a)に示すスラッシュ窒素の 場合、 $U_{i n}=1.5 、 2.0 \mathrm{~m} / \mathrm{s}$ の低流速時は流路上部に流速の最 大值が移動して上下非対称な流速分布（非均質流）となる。 $U_{i n}=3.0 \mathrm{~m} / \mathrm{s}$ 以上の高流速時は上下対称な流速分布（擬均 質流）となり、別途計算した液体窒素単相流の速度分布に 近づいている。固相率が 13 vol.\%より大きい場合には、高 流速になるほど流速分布が上下対称となる結果が得られた。 この結果は、入口流速 $U_{i n}=3.6 \mathrm{~m} / \mathrm{s}$ 以上で擬均質流となる 実験結果 ${ }^{4,6,7)}$ と一致している。Fig. 5 (b)に示すスラッシュ 水素の場合、 $1.5 \mathrm{~m} / \mathrm{s}$ の比較的低流速においても上下対称 な流速分布に近づいている。Fig. 6 (a)、Fig. 7 (a)、(b)に示 すように、スラッシュ窒素の固相率分布は低流速もしくは 粒子径が大きい場合が流路底部に固相が集中している。低 流速の場合、固体粒子の持つ慣性力よりも重力の影響が大 きくなるため固相が流路底部に集中する。固相率が大きい 底部では、固相と液相間の運動量交換、抗力の増加による 


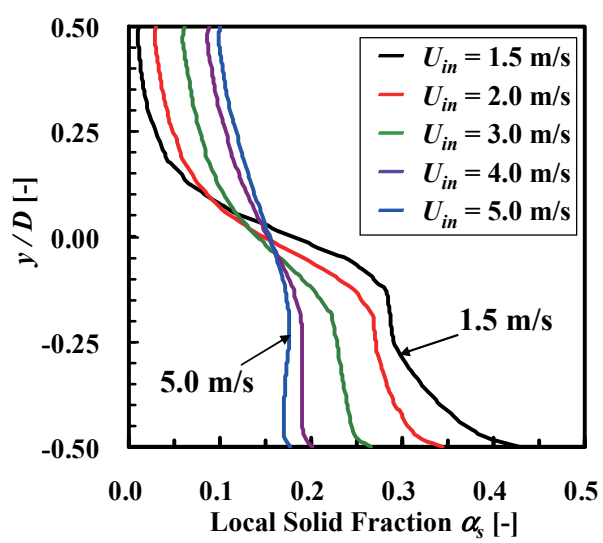

(a) Slush nitrogen.

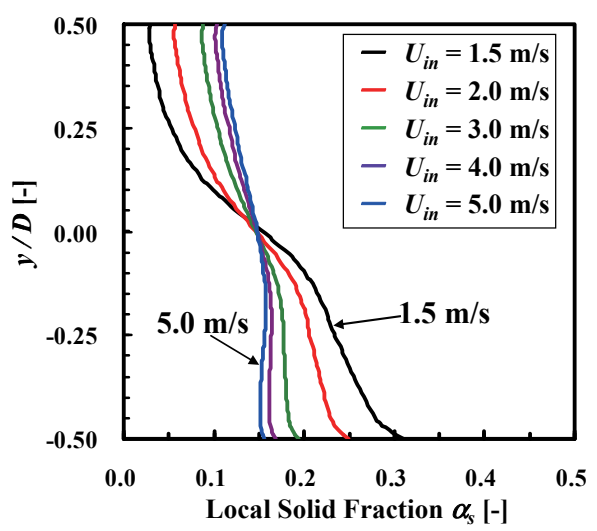

(b) Slush hydrogen.

Fig. 6 Solid fraction profiles according to changes in the inlet velocity $\left(d_{s}=1.3 \mathrm{~mm}, a_{s}=13 \mathrm{vol} . \%\right)$.

固相の運動量損失が大きくなり、流路上部と比べ速度が大 きく低下する。その結果、流速分布は Fig. 5 (a)に示すよう に上下非対称となる。粒子径が小さい場合 $\left(d_{s}=0.5 \mathrm{~mm}\right)$ の流速分布は示していないが、粒子径が大きい場合と比べ て、低流速時にも上下対称な流速分布に近づき、高流速時 の流速分布は粒子径の違いによる差が殆どない結果が得ら れた。同じ固相率では粒子径が小さい方が粒子数密度は大 きくなり、粒子拡散の影響が増大したことで低流速時でも 均一に分布し易くなったと考えられる。

スラッシュ水素の場合、スラッシュ窒素と同様な傾向を 示すが、Fig. 6 (b)、Fig. 7 (c)、(d)に示すように、低流速に おいてもスラッシュ窒素より均一な固相率分布を示す。

Table 1 に示すように、固液密度比がスラッシュ水素 1.12 、 スラッシュ窒素 1.18 であるため、スラッシュ水素の場合、 固相の慣性力に対する重力の影響が小さくなり、固相率は 流路底部で減少する。スラッシュ水素の固液密度比が小さ いことに加え、Table 1 に示すように液体水素の粘性が液 体窒素の粘性の $1 /(11.3)$ と小さく、固相と液相の干渉（抗 力）が小さくなるため、固相の流速分布がスラッシュ窒素 と比べ比較的低流速においても擬均質流になり易いと考え られる。低流速、高固相率、粒子径が大きい場合は、ス
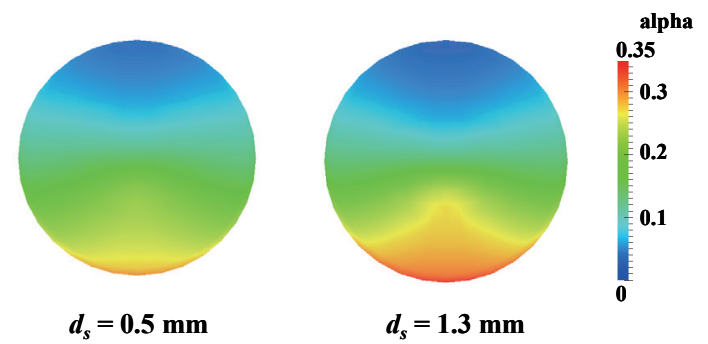

(a) Slush nitrogen $\left(U_{\text {in }}=2.0 \mathrm{~m} / \mathrm{s}\right)$.
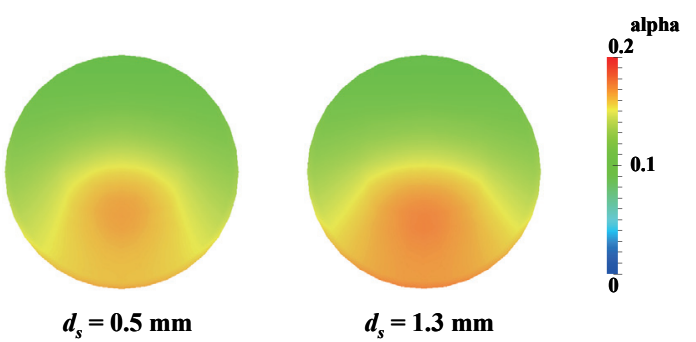

(b) Slush nitrogen $\left(U_{i n}=5.0 \mathrm{~m} / \mathrm{s}\right)$.
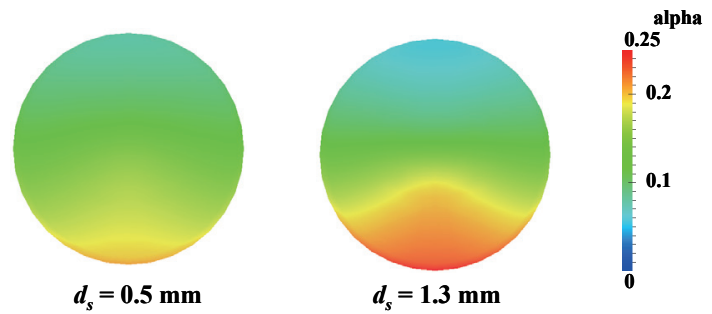

(c) Slush hydrogen $\left(U_{\text {in }}=2.0 \mathrm{~m} / \mathrm{s}\right)$
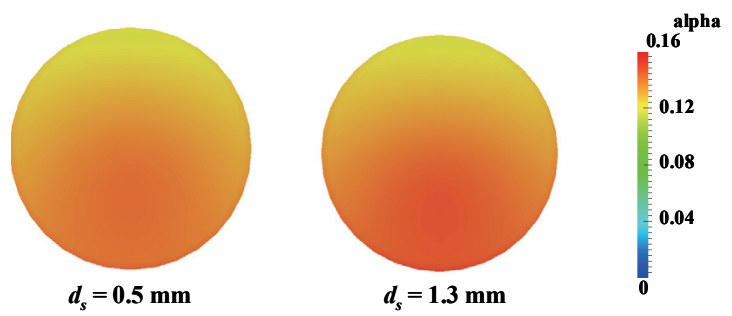

(d) Slush hydrogen $\left(U_{i n}=5.0 \mathrm{~m} / \mathrm{s}\right)$.

Fig. 7 Solid fraction profiles according to changes in the inlet velocity and solid particle diameter $\left(a_{s}=13 \mathrm{vol} . \%\right)$.

ラッシュ窒素の場合と同じ理由で固相が流路底部で増加し、 その結果、固相と液相間の干渉が増加するため流速分布が 上下非対称になる。

低流速においてスラッシュ水素の場合がスラッシュ窒素 よりも擬均質流になり易い前述の解析結果と、1. で述べた 圧力損失低減が擬均質流で現われる著者の実験結果 ${ }^{4,6,7)}$ の両者から、スラッシュ水素の圧力損失低減はスラッシュ 窒素に比べ低流速で出現すると推定される。実験結果から 以下、検証を行った。

液体水素の密度、粘性は液体窒素と比較して、いずれも 1/(11.3) と小さい（Table 1 に示すように両者の動粘性係数 はほぼ同じ值）ことから、スラッシュ水素、スラッシュ窒 素の流速 $U$ および管内径 $D$ が同じであれば、レイノルズ 数も同じ值となる。同じ固相率（17 vol.\%）で圧力損失低 


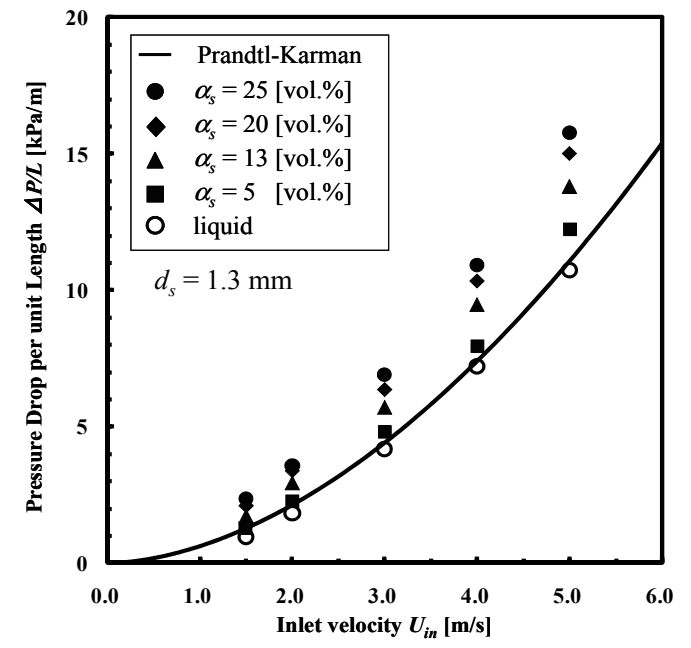

(a) Slush nitrogen.

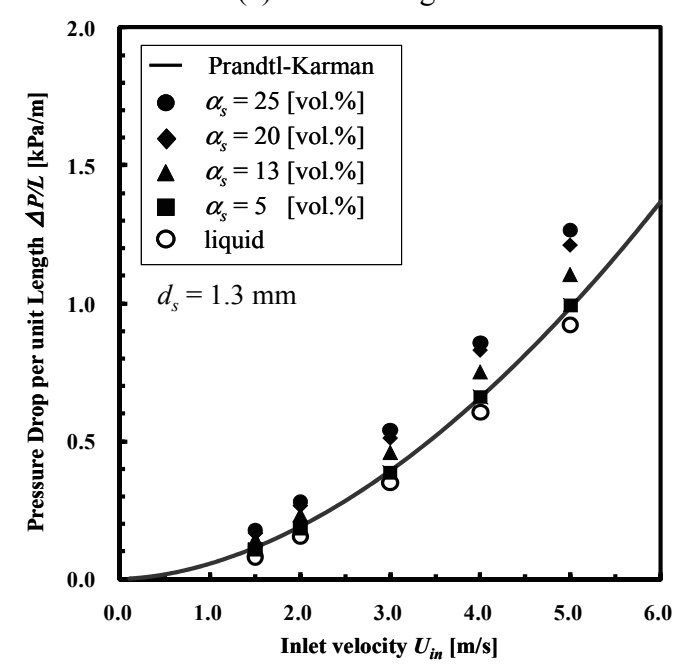

(b) Slush hydrogen.

Fig. 8 Pressure drop of the slush fluid and subcooled liquid according to changes in the solid fraction $\left(d_{s}=1.3 \mathrm{~mm}\right)$.

減効果が出現するレイノルズ数は、著者のスラッシュ窒素 実験 $(D=15 \mathrm{~mm})^{4,6)}$ では $R e=2 \times 10^{5} 、$ Sindt らのスラッ シュ水素実験 $(D=16.6 \mathrm{~mm})^{2)}$ では $R e=1 \times 10^{5}$ である。 即ち、固相率が同じであれば、圧力損失低減効果はスラッ シュ水素の方がスラッシュ窒素よりも低流速で出現するこ とを実験結果は示しており、スラッシュ水素の方がスラッ シュ窒素よりも擬均質流になり易いという解析結果の妥当 性を裏付けている。

\section{3 圧力損失特性}

サブクール液体窒素、サブクール液体水素（以下、液体 窒素、液体水素と記述）の入口流速 $U_{i n}=1.5 \sim 5.0 \mathrm{~m} / \mathrm{s}$ での 単位流路長さ当たりの圧力損失（以下、圧力損失と記述） の数值解析結果 (○印) と Prandtl-Karman 式による圧力損 失結果の比較を Fig. 8 に示す。圧力損失の計算は流路 $L=$ $400 \mathrm{~mm}$ と $450 \mathrm{~mm}$ の結果を用いた。数值解析結果と Prandtl-Karman 式の結果は良く一致しており、解析プログ ラムは平滑円管の圧力損失を十分な精度で予測できると考

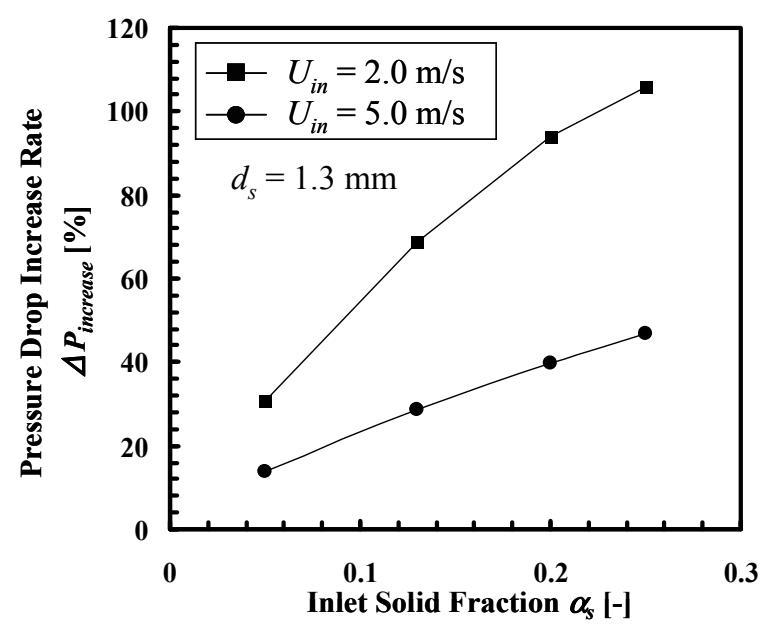

(a) Slush nitrogen $\left(U_{i n}=2.0\right.$ and $\left.5.0 \mathrm{~m} / \mathrm{s}\right)$.

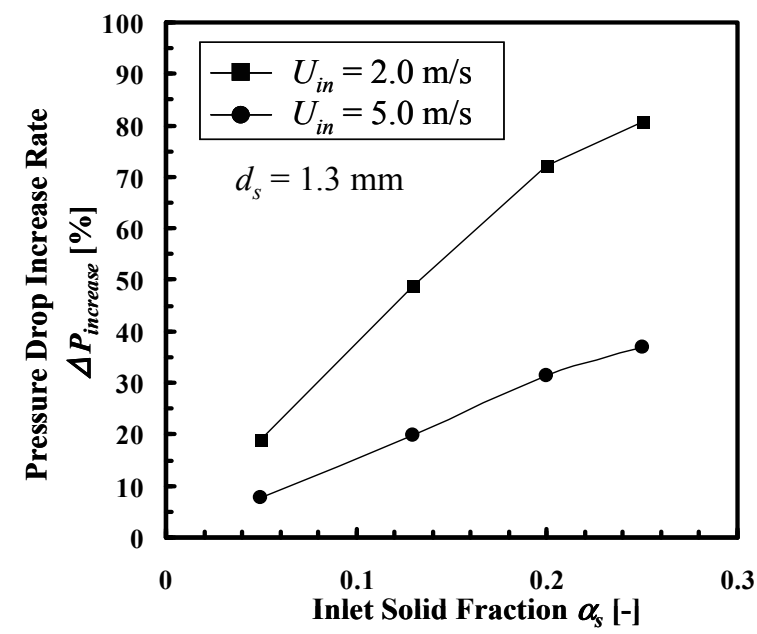

(b) Slush hydrogen $\left(U_{i n}=2.0\right.$ and $\left.5.0 \mathrm{~m} / \mathrm{s}\right)$.

Fig. 9 Pressure drop increase rate for the slush fluid based on the pressure drop of the subcooled liquid.

える。Fig. 8 にはスラッシュ窒素、スラッシュ水素の圧力 損失計算結果も示している。実際の流動では入口流速 $U_{i n}$ $=3.6 \mathrm{~m} / \mathrm{s}$ 以上において、スラッシュ窒素の圧力損失は圧 力損失低減効果により液体窒素よりも低下している $4,6,7) 。$ 実験で得られたスラッシュ窒素の圧力損失低減量の最大は、 流速 $4.2 \mathrm{~m} / \mathrm{s}$ 、固相率 $10 \mathrm{vol} . \%$ において、液体窒素と比較 して $23 \%$ である。本解析では圧力損失低減効果を考慮し ていないため、固液二相ニュートン流体としての圧力損失 計算結果である。以下、解析結果をもとに検討する。入口 流速、固相率の増加と共にスラッシュ窒素、スラッシュ水 素の圧力損失は増加している。固相率 $13 \mathrm{vol} \%$ 、入口流速 $U_{i n}=1.5 \sim 5.0 \mathrm{~m} / \mathrm{s}$ の場合、スラッシュ窒素とスラッシュ水 素の圧力損失比は Fig. 8 より 12 13 倍となっている。液体 窒素と液体水素の粘性係数比が 11.3 であることを考慮す ると、圧力損失の増大は固相と液相間の干渉が主な原因と 考えられる。

液体窒素、液体水素の圧力損失 $\Delta P_{l}$ に対するスラッシュ 窒素、スラッシュ水素の圧力損失 $\Delta P_{s l}$ の増加率を Fig. 9 に 


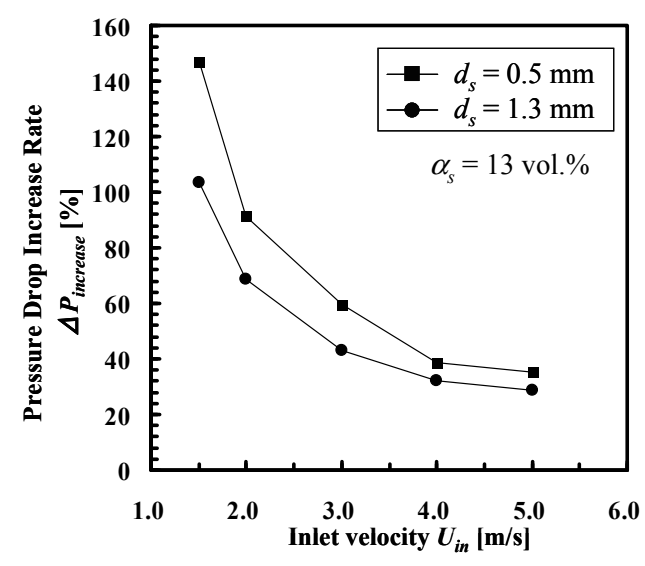

(a) Slush nitrogen $\left(d_{s}=0.5\right.$ and $\left.1.3 \mathrm{~mm}\right)$.

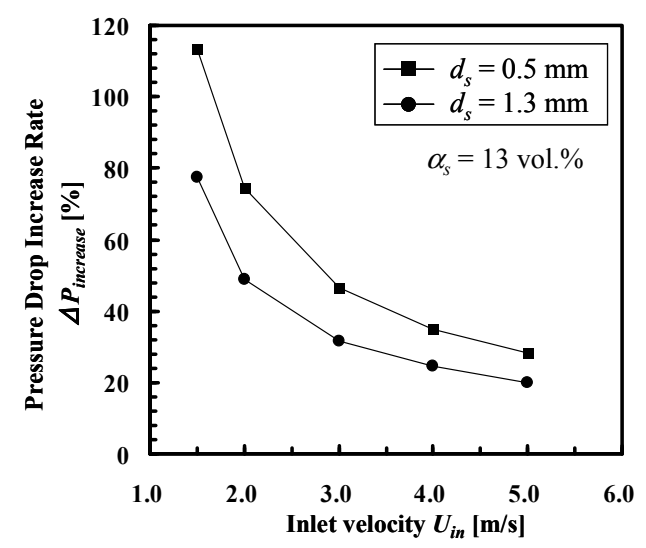

(a) Slush nitrogen $\left(d_{s}=0.5\right.$ and $\left.1.3 \mathrm{~mm}\right)$.

Fig. 10 Pressure drop increase rate for the slush fluid based on the pressure drop of the subcooled liquid ( $a_{s}=13$ vol.\%).

\section{示す。圧力損失増加率 $\Delta P_{\text {increase }}(\%)$ を式 $(21)$ で定義する。}

$$
\Delta P_{\text {increase }}=\left(\frac{\Delta P_{\text {sl }}}{\Delta P_{l}}-1\right) \times 100
$$

圧力損失は固相率の増加に伴い増加するが、同一固相率で 比較した場合、入口流速が大きい方が圧力損失増加率は小 さくなる。また、同一流速、同一固相率においては、ス ラッシュ水素の方が固液密度比が小さく、固相が均一に分 布するため、固相と液相間の干渉が小さくなり圧力損失増 加率が小さくなる。即ち、スラッシュ水素の方がスラッ シュ窒素よりも固相の影響が小さいことを意味する。

Fig. 10 に入口流速 $U_{i n}=1.5 \sim 5.0 \mathrm{~m} / \mathrm{s}$ 、粒子径 $d_{s}=0.5$ 、 $1.3 \mathrm{~mm}$ でのスラッシュ窒素、スラッシュ水素の圧力損失 増加率 $\Delta P_{\text {increase }}(\%)$ を示す。粒子径 $0.5 \mathrm{~mm}$ の圧力損失は示 していないが、同一流速、同一固相率で比較すると粒子径 $1.3 \mathrm{~mm}$ より圧力損失は増加している。また、Fig. 10 に示 すように、粒子径 $0.5 \mathrm{~mm}$ の場合が圧力損失増加率も大き くなっている。この理由は、液相の乱流エネルギー計算結 果から、同一固相率では粒子径が小さい場合が大きい場合 よりも粒子数が増加し、固相と液相の干渉が大きくなり、 液相の乱流エネルギーが増加するためである。粒子径 0.5、1.3 mm のいずれの場合も、入口流速の増加に伴い圧

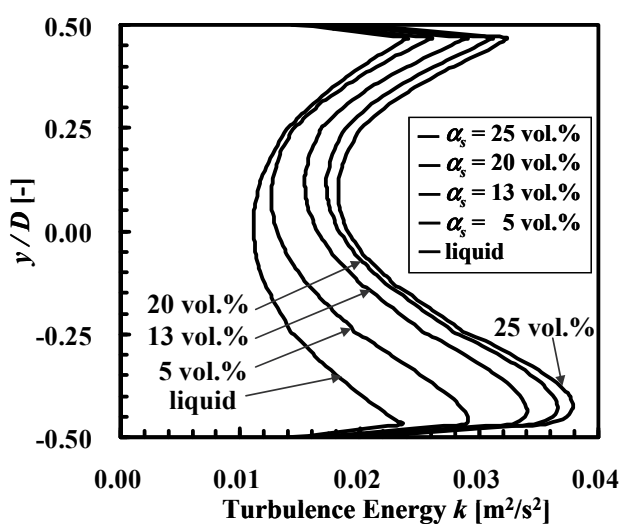

(a) Slush nitrogen $\left(U_{i n}=2.0 \mathrm{~m} / \mathrm{s}\right)$.

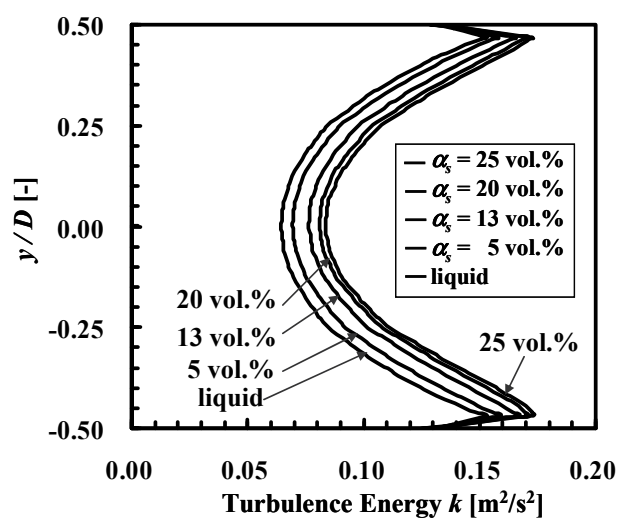

(b) Slush nitrogen $\left(U_{\text {in }}=5.0 \mathrm{~m} / \mathrm{s}\right)$.

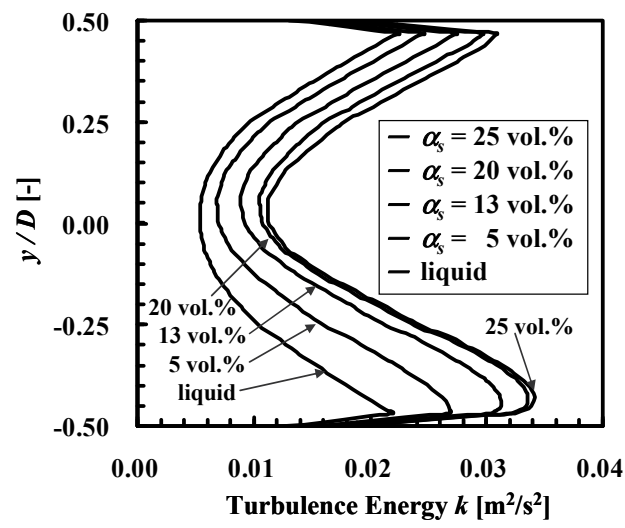

(c) Slush hydrogen $\left(U_{i n}=2.0 \mathrm{~m} / \mathrm{s}\right)$.

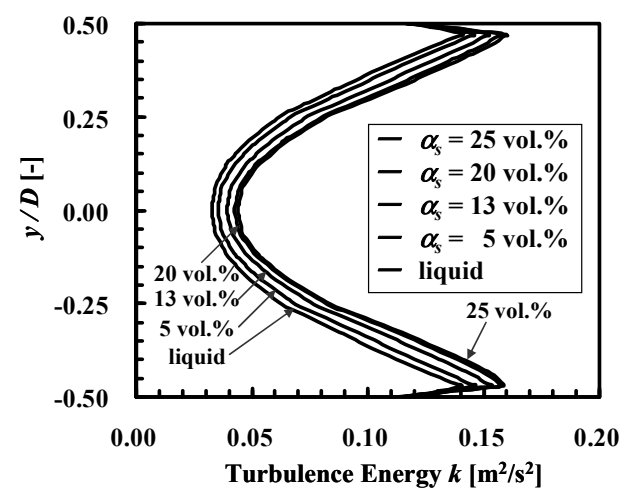

(d) Slush hydrogen $\left(U_{i n}=5.0 \mathrm{~m} / \mathrm{s}\right)$

Fig. 11 Turbulence energy profiles of the liquid phase according to changes in the solid fraction $\left(d_{s}=1.3 \mathrm{~mm}\right)$. 


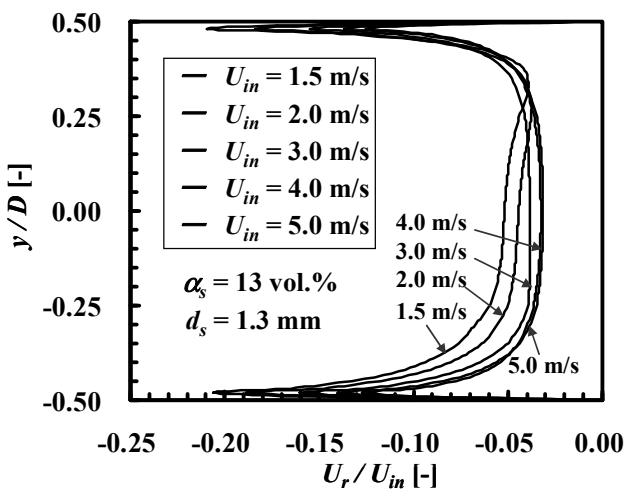

(a) Slush nitrogen.

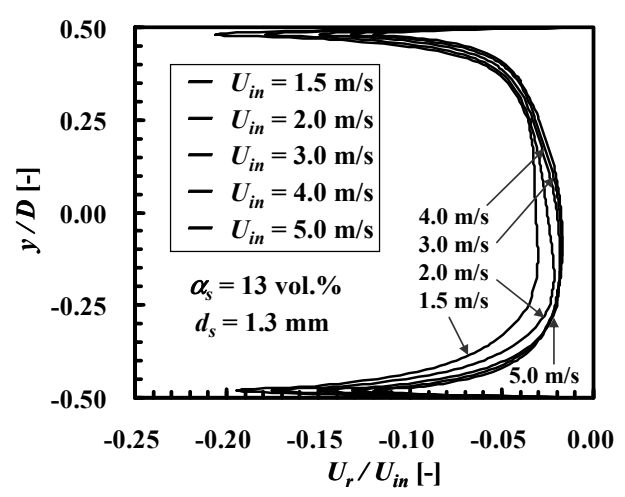

(b) Slush hydrogen.

Fig. 12 Ratios of the relative velocity between the solid and liquid phases to the inlet velocity $\left(d_{s}=1.3 \mathrm{~mm}, a_{s}=13 \mathrm{vol} . \%\right)$.

力損失増加率は小さくなっている。高流速においては液相 の乱流エネルギーが大きくなり、固相と液相間の干渉が相 対的に小さくなるためである。液相の乱流エネルギーの計 算結果から以下、考察する。

Fig. 11 にスラッシュ窒素、スラッシュ水素の固相率 $\alpha_{s}=$ 0.05 0.25 における管内での液相の乱流エネルギー分布を 示す。また、液体窒素、液体水素単相流（liquid）の乱流 エネルギー分布も併せて示す。固相率の増加により液相は 固相からの干渉を受け液相の乱流が増加する。Fig. 11(a)、

(c)に示す入口流速 $U_{i n}=2.0 \mathrm{~m} / \mathrm{s}$ の場合、液体と比較した固 相率増加に伴う乱流エネルギー増加量は $U_{i n}=5.0 \mathrm{~m} / \mathrm{s}$ の場 合よりも大きく、固相率が増加するほど上下非対称が顕著 となる乱流エネルギー分布になっている。これは、入口流 速が小さいと流路底部での固相が増加し、固相と液相の相 互干渉が増加するためである。一方、Fig. 11(b)、(d)に示 す入口流速 $U_{i n}=5.0 \mathrm{~m} / \mathrm{s}$ の場合、固相率の増加により乱流 エネルギーは増加するが、液体と比較した増加量は $U_{i n}=$ $2.0 \mathrm{~m} / \mathrm{s}$ の場合よりも小さく、乱流エネルギー分布はほぼ 上下対称である。入口流速 $U_{i n}=5.0 \mathrm{~m} / \mathrm{s}$ の場合、固相率の 大小に拘わらず流路全体に固相がほぼ均一に分布しており、 固相と液相の干渉が液相の乱流に与える影響は流路全体で ほぼ一様となるためである。また、Fig. 11 に示すスラッ シュ窒素とスラッシュ水素の乱流エネルギー分布を比較し

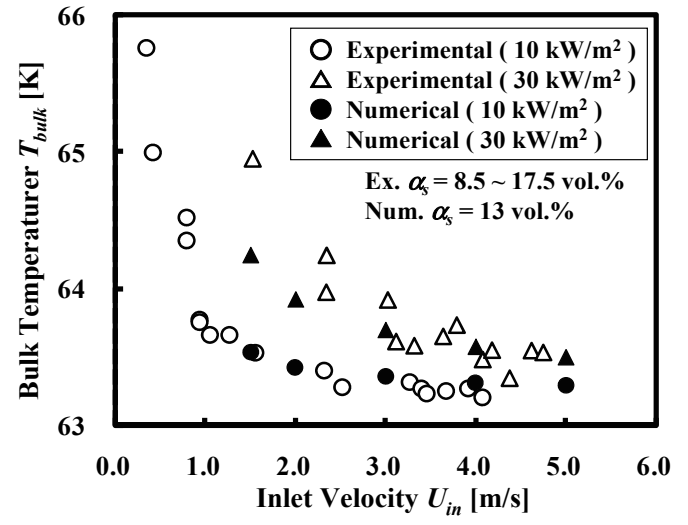

(a) Bulk temperature.

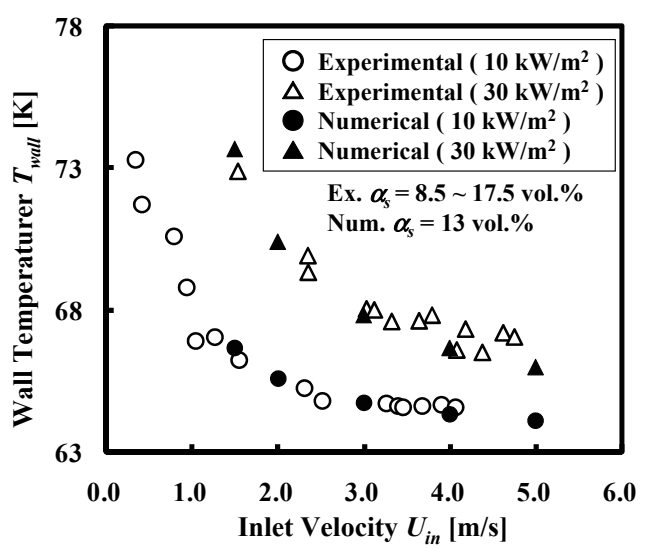

(b) Wall temperature.

Fig. 13 Comparisons of the bulk and wall temperatures between the numerical and experimental results for the slush nitrogen.

てみると、低流速、高流速時のいずれの場合もスラッシュ 窒素の乱流エネルギーの方が大きくなっている。Fig. 12 に入口流速で規格化したスラッシュ窒素、スラッシュ水素 の固相と液相間の相対速度 $\left(U_{r}=U_{s}-U_{l}\right)$ を示す。スラッ シュ窒素、スラッシュ水素のいずれの場合も高流速では固 体粒子の慣性力が増加するため、相対速度の絶対值は低流 速の方が高流速よりも大きい。従って、低流速の場合、固 相と液相の干渉が大きくなる。スラッシュ窒素とスラッ シュ水素を比較すると、低流速、高流速いずれの場合もス ラッシュ窒素の方が相対速度は大きくなっている。固液密 度比がスラッシュ窒素の方が大きく、固相が液相に追従し 難くなっているためと考えられる。その結果、スラッシュ 窒素の固相と液相間の干渉が増大し、Fig. 9、Fig. 10 に示 すようにスラッシュ窒素の圧力損失増加率はスラッシュ水 素よりも大きくなっている。

\section{4 熱伝達特性}

Fig. 13 はスラッシュ窒素が水平伝熱円管内を流動する場 合の入口流速変化による管中心部バルク温度 $T_{b u l k}$ および管 壁温度 $T_{\text {wall }}$ の実験と解析結果を示す。実験に用いた伝熱管 は内径 $15 \mathrm{~mm}$ 、伝熱長さ $810 \mathrm{~mm}$ であり、加熱開始点から 


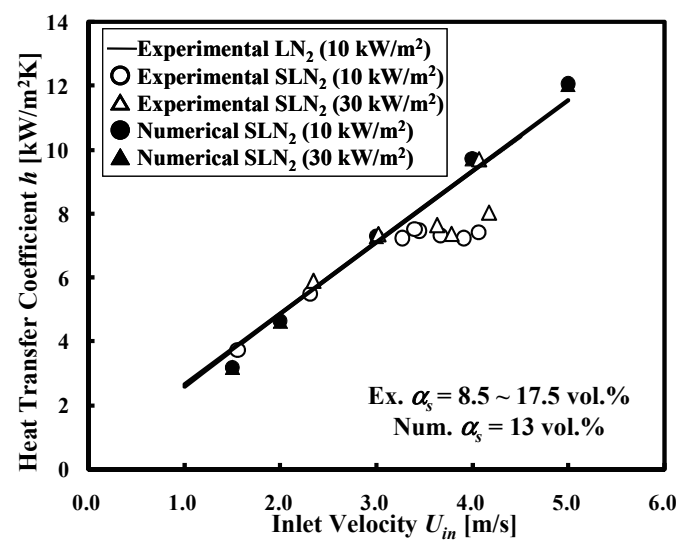

Fig. 14 Comparisons of the heat transfer coefficient between the numerical and experimental results for the slush nitrogen.

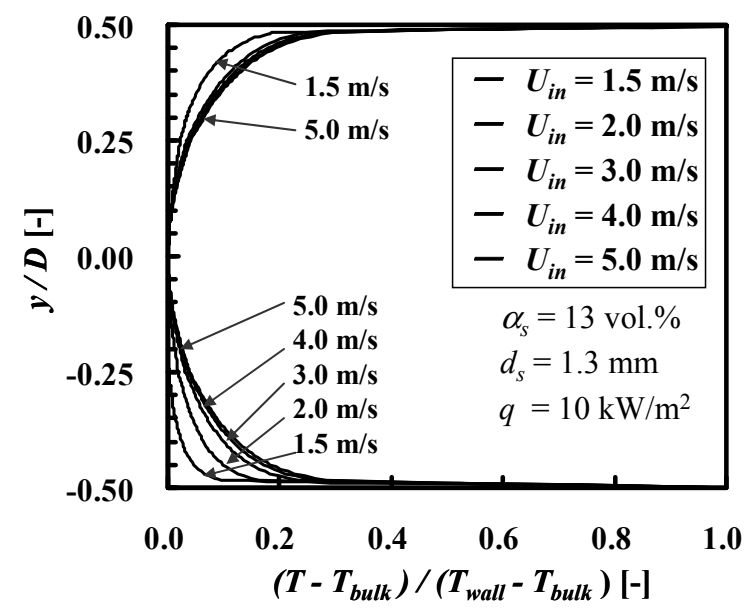

Fig. 15 Non-dimensional temperature profiles of the slush nitrogen according to changes in the inlet velocity $\left(d_{s}=1.3\right.$ $\mathrm{mm}, a_{s}=13$ vol. $\%, q=10 \mathrm{~kW} / \mathrm{m}^{2}$ ).

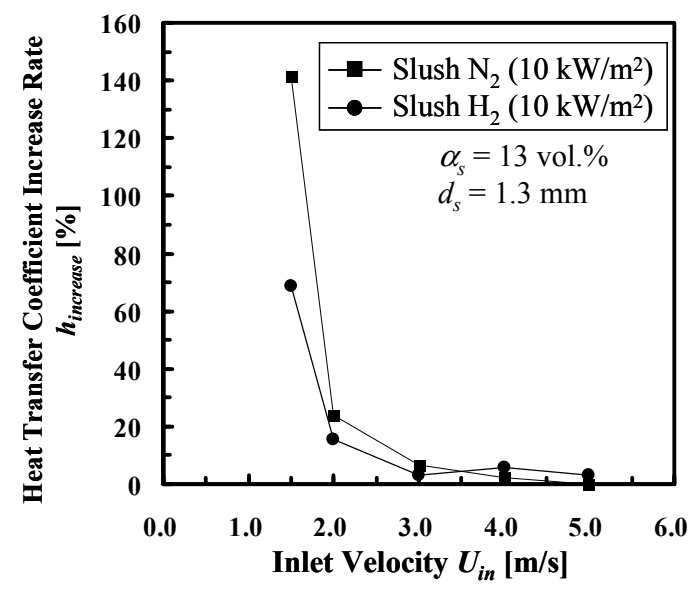

Fig. 16 Heat-transfer coefficient increase rate of the slush nitrogen and slush hydrogen based on the liquid nitrogen and liquid hydrogen $\left(d_{s}=1.3 \mathrm{~mm}, a_{s}=13 \mathrm{vol} . \%\right)$.

$705 \mathrm{~mm}$ での実験值である（固相率 $\alpha_{S}=8.5 \sim 17.5 \mathrm{vol} . \% ）{ }^{7)}$ 。 実験結果と比較するため、解析結果は $D=15 \mathrm{~mm} 、 L=810$ $\mathrm{mm}$ に変更して計算した場合の $L=705 \mathrm{~mm}$ での值である $\left(\alpha_{s}=13 \mathrm{vol} \%\right.$ 、 $\left.d_{s}=1.3 \mathrm{~mm}\right)$ 。熱流束はいずれも $q=10$ 、
$30 \mathrm{~kW} / \mathrm{m}^{2}$ とした。バルク温度、管壁温度共に入口流速の増 加と共に温度が低下しており、これは流速が大きくなる程、 質量流量が増加しスラッシュ窒素への伝熱量が相対的に小 さくなるためである。バルク温度の実験と解析結果の温度 差が最大 $0.8 \mathrm{~K}$ となる流速 $1.5 \mathrm{~m} / \mathrm{s}$ 、熱流束 $30 \mathrm{~kW} / \mathrm{m}^{2}$ の場合 を除いて、バルク温度および管壁温度の解析結果は実験結 果と良く一致している。Fig. 14 に数值解析結果から得られ たスラッシュ窒素の局所熱伝達係数と実験から得られた液 体窒素およびスラッシュ窒素の局所熱伝達係数 ${ }^{7)}$ を示す。 局所熱伝達係数は式(22)で計算した。

$$
h=q /\left(T_{\text {wall }}-T_{\text {bulk }}\right)
$$

実際の流動・伝熱では Fig. 14 に示すように入口流速 $U_{i n}=$ $3.0 \mathrm{~m} / \mathrm{s}$ 以上において、熱伝達劣化によりスラッシュ窒素

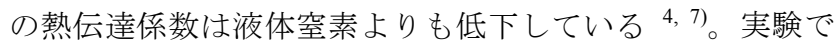
得られたスラッシュ窒素の熱伝達劣化量の最大は、液体窒 素と比較して $28 \%$ である。本解析では熱伝達劣化現象を 考慮していないため、固液二相ニュートン流体としての計 算結果であるが、伝熱時も実際の流動・伝熱を充分な精度 で解析できると考える。以下、解析結果をもとに検討す る。

入口流速 $U_{i n}=1.5 \sim 5.0 \mathrm{~m} / \mathrm{s}$ 、熱流束 $q=10 \mathrm{~kW} / \mathrm{m}^{2}$ でのス ラッシュ窒素の管内温度分布を Fig. 15 に示す。横軸はバ ルク温度と管壁温度によって規格化された無次元温度を示 す。 3.2 で入口流速 $U_{i n}=3.0 \mathrm{~m} / \mathrm{s}$ を境にして固相の流速分 布が非均質流から擬均質流になることを述べた。非均質流 となる低流速では温度分布は上下非対称となる。これは、 流路下部での固相率および液相の乱流エネルギーの増加に より、固相の融解が促進される結果、流路下部の温度は低 下し管壁近傍で急激に温度が上昇するためである。一方、 擬均質流となる流速 $3.0 \mathrm{~m} / \mathrm{s}$ 以上の高流速では、固相が管 内で均一に分布することから、温度は管壁近傍でなだらか に上昇し、温度分布は上下対称となる。また、流速が大き くなるほど乱流エネルギーが大きくなり熱伝達が促進され るため、高流速になるほど管壁近傍でなだらかな温度上昇 となる。スラッシュ水素の管内温度分布についても、Fig. 15 に示すスラッシュ窒素と同様な傾向が得られた。

熱流束 $q=10 \mathrm{~kW} / \mathrm{m}^{2}$ での液体窒素、液体水素の熱伝達 係数 $h_{l}$ に対するスラッシュ窒素、スラッシュ水素の熱伝 達係数 $h_{s l}$ の増加率を Fig. 16 に示す。熱伝達係数増加率 $h_{\text {increase }}(\%)$ を式(23)で定義する。

$$
h_{\text {increase }}=\left(\frac{h_{s l}}{h_{l}}-1\right) \times 100
$$

スラッシュ窒素、スラッシュ水素共に、流速の増加に伴い 熱伝達係数増加率は単調減少しており、流速 $3.0 \mathrm{~m} / \mathrm{s}$ 以上 の擬均質流では増加率は数\%程度に小さくなる。低流速で は、スラッシュ窒素の熱伝達係数増加率はスラッシュ水素 と比較して大きくなる。スラッシュ窒素の場合、窒素の固 液密度比、粘性が大きいため、固相と液相間の干渉が大き 

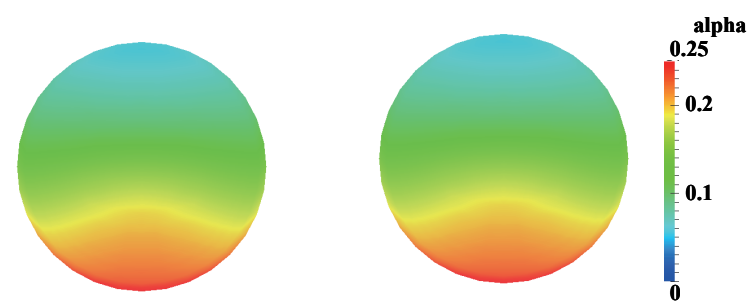

Slush nitrogen (left: $q=0 \mathrm{~kW} / \mathrm{m}^{2}$, right: $q=30 \mathrm{~kW} / \mathrm{m}^{2}$ ).
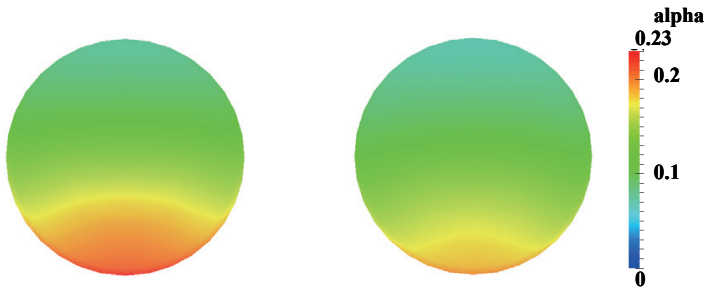

Slush hydrogen (left: $q=0 \mathrm{~kW} / \mathrm{m}^{2}$, right: $q=30 \mathrm{~kW} / \mathrm{m}^{2}$ ).

(a) Low inlet velocity $\left(U_{i n}=2.0 \mathrm{~m} / \mathrm{s}\right)$.
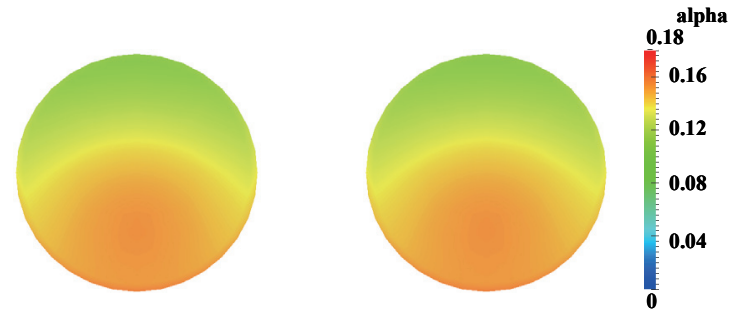

Slush nitrogen (left: $q=0 \mathrm{~kW} / \mathrm{m}^{2}$, right: $q=30 \mathrm{~kW} / \mathrm{m}^{2}$ ).
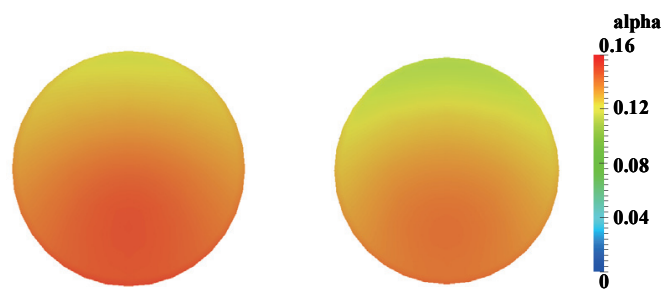

Slush hydrogen (left: $q=0 \mathrm{~kW} / \mathrm{m}^{2}$, right: $q=30 \mathrm{~kW} / \mathrm{m}^{2}$ ).

(b) High inlet velocity $\left(U_{\text {in }}=5.0 \mathrm{~m} / \mathrm{s}\right)$.

Fig. 17 Solid fraction profiles according to changes in the inlet velocity and heat flux $\left(d_{s}=1.3 \mathrm{~mm}, a_{s}=13 \mathrm{vol} . \%\right)$.

くなり、液相の乱れエネルギーが大きくなる結果、熱伝達 が促進されると考えられる。

Fig. 17 に非加熱、加熱 $\left(q=30 \mathrm{~kW} / \mathrm{m}^{2}\right)$ 時のスラッシュ 窒素、スラッシュ水素の管断面における固相率分布を示す。 Fig. 17(a)に示寸入口流速 $U_{i n}=2.0 \mathrm{~m} / \mathrm{s}$ の場合、水素の固液 密度比が窒素の $1 /(11.3)$ と小さいため、スラッシュ水素は スラッシュ窒素と比較して固相が均一に分布している。ま た、スラッシュ水素は、スラッシュ窒素と比べて融解潜熱 が 1/(4.82)と小さいため、非加熱の場合と比較して管底部 で固相が多く融解しており、加熱により固相の融解が促進 されている。Fig. 17(b)に示す $U_{i n}=5.0 \mathrm{~m} / \mathrm{s}$ の場合、スラッ シュ窒素、スラッシュ水素のどちらの場合も固相がほぼ均 一に分布しているが、スラッシュ水素の場合は加熱時に若
干ではあるが管内の固相率が低下している。高流速時に固 相の融解が顕著でないのは、質量流量の増加により加熱量 が相対的に小さくなるためである。

\section{4. まとめ}

水平円管内を流動するスラッシュ流体の三次元流動・伝 熱特性を解析するため、熱非平衡二流体モデルを用いた三 次元流動・伝熱解析コード（SLUSH-3D）を開発し、次の 解析結果が得られた。

（1）流速分布、乱流強度、圧力損失、熱伝達係数は著者の PIV 法等による実験結果と定量的もしくは定性的に良い一 致を示した。スラッシュ流体の流動・伝熱特性を十分な精 度で解析できると考える。圧力損失低減、熱伝達劣化を本 解析コードで考慮することは今後の課題である。

(2) 円管内の固相流速分布、固相率分布、乱流エネル ギー、圧力損失はスラッシュ流体の流速、固相率、固体粒 子径の影響を強く受ける。低流速、高固相率、粒子径が大 きいほど、固相率は管底部で増大し、固相流速分布、固相 率分布が上下非対称（非均質流）となる。一方、高流速、 低固相率、粒子径が小さいほど、固相流速分布、固相率分 布は上下対称（擬均質流）に近くなる。

(3) 固相率が大きい場合、固相と液相の干渉が増大し、乱 流エネルギーが増大して圧力損失は大きくなる。入口流速 が大きい場合、固相の存在による液相の乱流エネルギー増 加は、入口流速増加に起因する液相の乱流エネルギー増加 よりも相対的に小さくなり、流速増加による圧力損失増加 率は小さくなる。粒子径が小さい場合、同一固相率では粒 子数が増加するため、液相の乱流エネルギーが増加して、 圧力損失および圧力損失増加率が増加する。

（4）伝熱時の流動、熱伝達特性については、非加熱時の流 動特性、即ち、非均質流、擬均質流に対応して伝熱時の管 内温度分布が上下非対称、上下対称となり、流動と伝熱が 相互に密接に関係している。

（5）スラッシュ窒素とスラッシュ水素の流動・伝熱特性を 比較した結果、水素の場合、固液密度比、液体の粘性係数 が窒素よりも小さいため、スラッシュ水素はスラッシュ窒 素よりも低流速において擬均質流に近くなる。これは、ス ラッシュ水素の圧力損失低減がスラッシュ窒素よりも低流 速で出現することを示しており、スラッシュ窒素、スラッ シュ水素の実験結果と一致している。また、スラッシュ水 素の場合、窒素に対する水素の融解潜熱が $1 /(4.82)$ と小さ いため、加熱による固相の融解が低流速時に顕著となる。

本研究の一部は、科学研究費補助金（基盤 B21360091） により実施した。計算の実行には東北大学流体科学研究所 のスーパーコンピュータを使用した。 


\section{記号表 (Nomenclature)}

\begin{tabular}{|c|c|c|c|}
\hline$C_{p}$ & specific heat at constant pressure & $N u$ & Nusselt number [-] \\
\hline & {$[\mathrm{J} /(\mathrm{kg}-\mathrm{K})]$} & $\operatorname{Pr}$ & Prandtl number [-] \\
\hline$D$ & pipe diameter $[\mathrm{mm}]$ & $\operatorname{Re}$ & Reynolds number [-] \\
\hline$d s$ & solid particle diameter [mm] & Sc & Schmidt number [-] \\
\hline g & gravitational acceleration $\left[\mathrm{m} / \mathrm{s}^{2}\right]$ & \multicolumn{2}{|c|}{ Greeks } \\
\hline$h$ & heat transfer coefficient $\left[\mathrm{W} /\left(\mathrm{m}^{2}-\mathrm{K}\right)\right]$ & $\alpha$ & phase fraction [-] \\
\hline$h_{L}$ & latent heat of fusion $[\mathrm{J} / \mathrm{kg}]$ & $\varepsilon$ & energy dissipation rate $\left[\mathrm{m}^{2} / \mathrm{s}^{3}\right]$ \\
\hline I & unit matrix [-] & $\kappa$ & thermal conductivity $[\mathrm{W} /(\mathrm{m}-\mathrm{K})]$ \\
\hline$k$ & turbulence energy $\left[\mathrm{m}^{2} / \mathrm{s}^{2}\right]$ & $\mu$ & viscosity [Pa-s] \\
\hline$L$ & pipe length $[\mathrm{mm}]$ & $v$ & kinematic viscosity $\left[\mu \mathrm{m}^{2} / \mathrm{s}\right]$ \\
\hline \multirow[t]{2}{*}{$\boldsymbol{M}$} & quantity of momentum transport & $\rho$ & density $\left[\mathrm{kg} / \mathrm{m}^{3}\right]$ \\
\hline & at phase boundary $\left[\mathrm{kg} /\left(\mathrm{m}^{2}-\mathrm{s}^{2}\right)\right]$ & $\tau$ & viscous stress tensor $[\mathrm{Pa}]$ \\
\hline$m$ & $\operatorname{mass}[\mathrm{kg}]$ & \multicolumn{2}{|c|}{ Subscripts and Superscripts } \\
\hline$\dot{m}$ & mass genaration rate $\left[\mathrm{kg} /\left(\mathrm{m}^{3}-\mathrm{s}\right)\right]$ & \multicolumn{2}{|c|}{ cell cell } \\
\hline$n$ & density of particle number $\left[1 / \mathrm{m}^{3}\right]$ & eff & effctive value \\
\hline$P$ & pressure $[\mathrm{Pa}]$ & $\varphi$ & solid or liquid phase \\
\hline \multirow[t]{2}{*}{$Q$} & quantity of heat transport & in & inlet value \\
\hline & at phase boundary $\left[\mathrm{W} / \mathrm{m}^{3}\right]$ & $L$ & latent heat of fusion \\
\hline$q$ & heat flux $\left[\mathrm{W} / \mathrm{m}^{2}\right]$ & $l$ & liquid phase \\
\hline $\boldsymbol{R}$ & Reynolds stress [Pa] & $r$ & relative value \\
\hline$r$ & pipe radius $[\mathrm{mm}]$ & $s$ & solid phase \\
\hline$T$ & absolute temperature $[\mathrm{K}]$ & $s l$ & slush fluid \\
\hline$t$ & time $[\mathrm{s}]$ & $t$ & turbulent flow \\
\hline $\boldsymbol{U}$ & flow velocity $[\mathrm{m} / \mathrm{s}]$ & $T$ & transposed, phase change \\
\hline \multirow[t]{2}{*}{$u$} & $x$ component of fluctuating & $t r$ & triple point \\
\hline & velocity $[\mathrm{m} / \mathrm{s}]$ & $v m$ & virtual mass \\
\hline$u^{\prime}$ & r. m. s. velocity of $u[\mathrm{~m} / \mathrm{s}]$ & $x$ & $x$ component \\
\hline
\end{tabular}

\section{参 考 文 献}

1) K. Ohira: "Liquid and slush hydrogen: Its application and technology development," TEION KOGAKU 41 (2006) 61-72 (in Japanese)

大平勝秀：「液体水素およびスラッシュ水素技術の現状と応 用」, 低温工学 41 (2006) 61-72

2) C. F. Sindt and P. R. Ludtke: "Slush hydrogen flow characteristics and solid fraction upgrading," Adv. Cryo. Eng. 15 (1970) 382-390

3) K. Matsuo, M. Ikeuchi, A. Machida and K. Yasuda: "Fundamental study of pipe flow and heat transfer characteristics of slush nitrogen,” Adv. Cryo. Eng. 51 (2006) 1033-1040

4) K. Ohira, M. Nozawa, J. Ishimoto, N. Koizumi and T. Kamiya: "Pressure drop reduction of slush nitrogen in turbulent pipe flows," Adv. Cryo. Eng. 53A (2008) 67-74

5) K. Ohira, N. Takahashi, M. Nozawa and J. Ishimoto: "Heat transfer and pressure drop reduction of slush nitrogen in a turbulent pipe flow," Proc. of ICEC 22 (2009) 353-358

6) K. Ohira: "Pressure drop reduction phenomenon of slush nitrogen flow in a horizontal pipe,” Cryogenics 51 (2011) 389-396 大平勝秀：「水平管内を流動するスラッシュ窒素の圧力損失 低減現象」, 低温工学 45 (2010) 484-492

7) K. Ohira, K. Nakagomi and N. Takahashi: "Pressure-drop reduction and heat-transfer deterioration of slush nitrogen in horizontal pipe flow," Cryogenics 51 (2011) (in press)

大平勝秀, 中込圭, 高橋則史 : 「水平管内を流動するスラッ シュ窒素の圧力損失低減および伝熱劣化特性に関する研究」, 低温工学 46 (2011) 148-160
8) D.E. Daney, V. D. Arp and R. O. Voth: "Hydrogen slush production with a large auger," Adv. Cryo. Eng. 35 (1990) 17671776

9) K. Ohira: "Study of production technology for slush hydrogen," Adv. Cryo. Eng. 49 (2004) 56-63

10) D. H. Weitzel, J. E. Cruz, R. J. Richards, L. T. Lowe and D. B. Mann: "Instrumentation for storage and transfer of hydrogen slush," Adv. Cryo. Eng. 16 (1971) 230-240

11) D. A. Ellerbruch: "Microwave method for cryogenic liquid and slush instrumentation," Adv. Cryo. Eng. 16 (1971) 241-250

12) K. Ohira and K. Nakamichi: "Development of a high-accuracy capacitance-type densimeter for slush hydrogen," JSME Int. J., Ser. B 43 (2000) 162-170

大平勝秀, 中道憲治 : 「スラッシュ水素用静電容量型高精度 密度計の開発研究」, 日本機械学会論文集（B 編）65 (1999) 1438-1445

13) K. Ohira: "Development of density and mass flow rate measurement technologies for slush hydrogen," Cryogenics 44 (2004) 59-68

14) F. Gamma, L. del Monte and R. Liberatore: "CFD-analysis of slush hydrogen flows in feed-systems of rocket-based combined cycles," AIAA-98-3226 (1998)

15) P. Crivellari, L. del Monte and F. Gamma: "Computational fluid dynamics of slush hydrogen for aerospace vehicles," AIAA-992243 (1999)

16) J. Ishimoto and R. Ono: "Numerical study of the two-phase flow characteristics of slush nitrogen," Cryogenics 45 (2005) 304-316 石本淳, 大野隆介：「スラッシュ窒素の二相流動特性に関す る数值解析」, 低温工学 39 (2004) 463-474

17) H. Rusche: "Computational fluid dynamics of dispersed two-phase flow at high phase fractions," Ph.D. thesis, University of London (2002)

18) J. H. Ferzigger and M. Peric: "Computational Methods for Fluid Dynamics (2nd Ed.)," Springer-Verlag, Berlin (1996) 279-286

19) L. S. Fan and C. Zhu: "Principles of Gas-Solid Flows," Cambridge Univ. Press, New York (1998) 87-129

20) D. Gidaspow: "Multiphase flow and fluidization," Academic Press, San Diego (1994) 197-238

21) C. Crowe, M. Sommerfeld and Y. Tsuji: "Multiphase Flows with Droplets and Particles," CRC Press, Boca Raton (1998) 60-63

22) "OpenFOAM 1.5 User Guide," Free software foundation Inc. (2008)

23) R. F. Barron: "Cryogenic Heat Transfer," Taylor \& Francis, Philadelphia, PA (1999) 200-206

24) R. D. McCarty: "Hydrogen technological survey-Thermophysical properties," NASA SP-3089 (1975)

25) J. O. Hinze: “Turbulence," McGraw-Hill Book Co., Inc., New York, (1959) 1-13 
大 平 勝 秀 1973 年九州大学工学部航空工学科卒業。

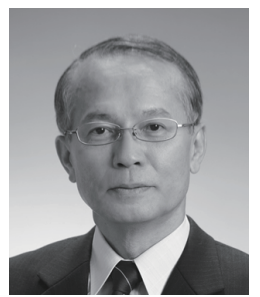
1975 年同大学院工学研究科修士課程修了。 1975 年三菱重工業 (株) 長崎研究所勤務。液 体水素に関する極低温技術、H- I 、 H- II 口 ケットの開発に従事。2004 年 7 月より東北 大学流体科学研究所極低温流研究分野 教授。主に、固液（スラッシュ）二相流、 気液二相流など極低温流体の流動、伝熱お よび水素エネルギー利用技術の研究に従事。低温工学・超電導学 会、日本混相流学会、日本機械学会、日本航空宇宙学会などの会 員。博士 (工学)。

太田敦人

2009 年東北大学工学部機械知能・航空工

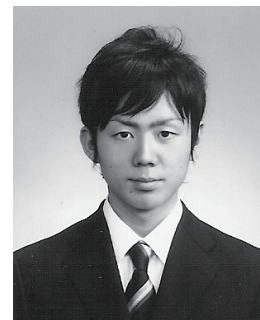
学科卒業。2009 年同大学院工学研究科修士 課程入学。主に極低温固液（スラッシュ） 二相流体の流動、伝熱特性に関する数值解 析研究に従事。2011 年同大学院工学研究科 修士課程修了。2011 年 4 月より三菱商事 （株）勤務。

向 井康 晃 2007 年東北大学工学部機械知能 - 航空工 学科卒業。2007 年同大学院工学研究科修士課程入学。主に極低 温固液 (スラッシュ) 二相流体の流動特性に関する数值解析研究 に従事。2009 年同大学院工学研究科修士課程修了。2009 年 4 月 より AGC 旭硝子（株）勤務。

細 野 琢 巳

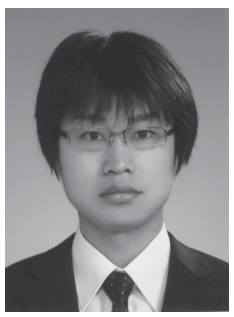

2011 年東北大学工学部機械知能・航空工 学科卒業。2011 年同大学院工学研究科修士 課程入学。主に極低温固液（スラッシュ）二 相流体の流動、伝熱特性に関する数值解析研 究に従事。 